\title{
Pengembangan Service Automation Application dengan Pendekatan Customer Self-Service (Studi Kasus: Martabak Djoeragan Pekanbaru)
}

\author{
Boby Chandra Panjaitan, Juni Nurma Sari, Anggy Trisnadoli
}

Jurusan Teknologi Informasi, Politeknik Caltex Riau

\section{KEYWORDS}

Customer Relationship Management, Service

Automation, Customer Self Service, Martabak

Djoeragan.

\section{CORRESPONDENCE}

Phone: 082137661424

E-mail: bobychandra@alumni.pcr.ac.id

\section{PENDAHULUAN}

Martabak Djoeragan merupakan usaha kuliner martabak telah telah berdiri selama kurang lebih 5 tahun dan sudah memiliki 6 toko yang ada di kota pekanbaru. Biasanya toko Martabak Djoeragan buka setiap hari dan jam buka toko dimulai dari jam 6 sore sampai jam 11 malam. Kreasi rasa Martabak Djoeragan yang menarik dan lezat membuat orang rela mengantri untuk mendapatkan jenis martabak yang di inginkan karena rasa dan terjangkau di semua kalangan. Berdasarkan grafik data transaksi penjualan jumlah rata-rata penjualan penjualan martabak Djoeragan pada tahun 2017 rata-rata 300 pesanan dalam sehari. Tentunya dengan pesaanan yang begitu banyak membuat kerumitan dalam menangani pesanan pelanggan di bidang pelayanan.

Saat ini proses pelayanan di toko Martabak Djoeragan menggunakan sistem kasir manual. Pelayanan pada sistem kasir manual yaitu pelanggan mendatangi kasir untuk bertanya mengenai informasi martabak dan memesan martabak, lalu pegawai kasir menginputkan pesanan pelanggan, kemudian apabila pelanggan sudah membayar pesanannya maka pegawai kasir akan memberikan struk belanja pelanggan. Setelah Pesanan selesai kasir akan memanggil pelanggan sesuai dengan nama pemesan.
Proses pelayanan yang ada saat ini memiliki masalah yaitu tidak memberikan kemudahan maksimal pada proses penjulan Martabak Djoeragan maka dengan dibangunnya aplikasi service automation dengan fungsionalitas customer self-service dengan teknologi web self-service diharapkan pelayanan menjadi mudah dan penjulaan mengalami peningkatan.

\section{SERVICE AUTOMATION DALAM BISNIS PENJUALAN}

Berdasarkan penelitian terdahulu yang dilakukan oleh Lestari [1], Putra \& Winarno [2], Nugroho \& Djajalaksana [3], Setiawan \& Susanti [4] dan Prabowo [5] membahas tentang penerapan pelayanan otomatis atau service automation dalam bisnis penjualan yang menghasilkan pembangunan aplikasi service automation dalam memberikan kemudahan di bidang pelayanan. Aplikasi yang terkomputerisasi secara otomatis ini mampu dengan mudah mengurangi pekerjaan atau proses yang dilakukan manusia. Dalam penggunanya aplikasi ini menggunakan web sebagai media penghubung antara pelanggan atau user dengan pedagang yang telah di teliti oleh peneliti terdahulu. Kesimpulan yang dapat diambil dari penelitian yang telah dilakukan sebelumnya aplikasi service automation dengan pendekatan 
customer self-service bertujuan untuk menjalin hubungan baik dengan pelanggan dalam memberikan kemudahan pelayanan.

Dalam kerangka operasionalnya Customer Relationship Management memiliki konsep service automation yaitu aplikasi teknologi terkomputerisasi untuk mendukung staf layanan dan manajemen dalam pencapaian tujuan yang berhubungan dengan pekerjaan. Jenis dukungan elektronik yang memungkinkan pengguna akhir untuk menggunakan teknologi untuk mengakses informasi dan melakukan tugas-tugas rutin tanpa memerlukan bantuan perwakilan layanan orang.

Dengan teknologi customer self-service pada service automation menyediakan tools bagi pelanggan untuk menjalankan aktifitasaktifitas yang sebelumnya dilakukan oleh kasir menggunakan web. Dalam penggunaan Web pelanggan pelanggan dapat memperoleh pelayanan lebih mudah, tanggapan yang lebih cepat, konsisten, dan terkadang lebih akurat, kemungkinan untuk memperoleh informasi yang lebih detail serta memberikan kepuasan bagi pelanggan.

Sedangkan keuntungan yang diperoleh bagi usaha martabak djoeragan memberikan pelayanan lebih tanpa perlu menambah karyawan, memperkuat mengurangi kerja kasir dan meningkatkan kualitas pelayanan yang dapat diberikan kepada pelanggan.

\section{BISNIS PROSES MARTABAK DJOERAGAN}

Martabak Djoeragan adalah usaha dalam bidang kuliner di pekanbaru yang di rintis oleh bapak Riski Fitri yang dimana beliau membuat sebuah kreasi makanan pada martabak. Pedagang martabak banyak kita jumpai berjualan di kaki lima atau menjual martabak dengan menggunakan gerobak karena makanan ini termasuk makanan khas indonesia. Kini usaha kuliner Martabak Djoeragan telah telah berdiri selama kurang lebih 5 tahun dan sudah ada 9 toko di kota pekanbaru.

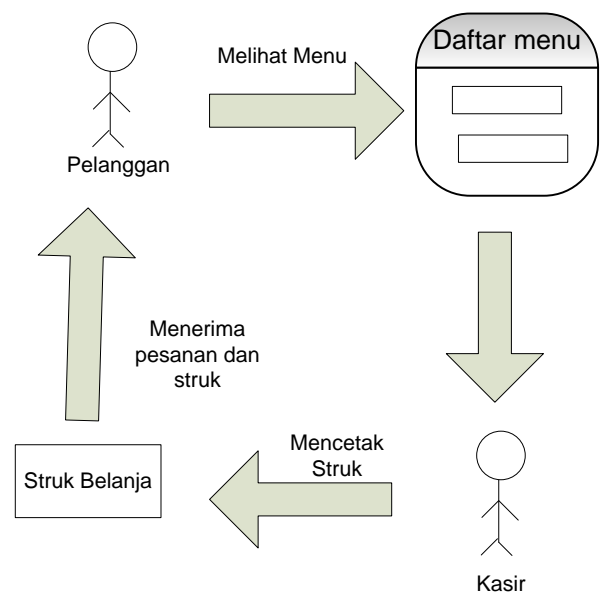

Gambar 1. Proses Pelayanan Martabak Djoeragan

Pada gambar 1 menjelaskan proses pelayanan di toko martabak djoeragan yaitu Pertama, pelanggan memesan secara langsung ke kasir untuk bertanya mengenai informasi martabak yang terdapat pada daftar menu lalu memesan martabak yang di inginkan. Kedua, pegawai kasir menginputkan pesanan pelanggan menggunakan sistem kasir. Ketiga, pelanggan membayar pesanannya dan menerima struk belanja. Keempat, pelanggan menunggu pesanan selesai di masak apabila pesanan selesai kasir akan memanggil sesuai dengan nama pelanggan untuk mengambil pesanannya.

\section{METODOLOGI PENELITIAN}

Secara umum penelitian ni dilakukan dengan berbagai tahapan proses secara berurutan, sehingga target yang diharapkan dapat tercapai seperti yang ditunjukkan pada Gambar 2 sebagai berikut

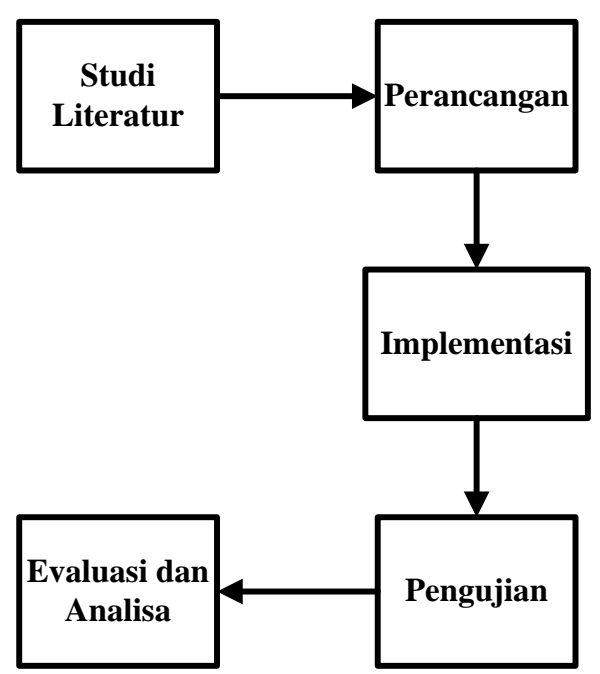

Gambar 2. Metode Penelitian

Pada gambar 2 menjelaskan mengenai tahapan metodologi penelitian yang dilakukan dalam membuat aplikasi ini sebagai berikut.

Tahap pertama melakukan studi literatur yaitu pengumpulan kebutuhan fungsioal dari pengguna dengan cara wawancara, diskusi, tinjauan pustaka dan perumusan masalah yang dilakukan langsung dengan kepala toko martabak djoeragan pekanbaru.

Kemudian setelah mengumpulkan kebutuhan maka melakukan perancangan yaitu proses pembuatan arsitektur sistem meliputi: pertama, perancangan aliran proses dari aplikasi yaitu pembuatan flowchart sesuai demgan proses yang ada. Kedua perancangan spesifikasi pengguna dengan kebutuhan dari aplikasi yaitu use case dengan 3 pengguna.

Ketiga. perancangan entitas-entitas dari tabel database yang dibutuhkan yaitu ERD berdasarkan data-data yang dibutuhkan. Keempat, perancangan gambaran menu-menu yang akan terdapat di aplikasi yaitu site map. Kelima, perancangan prototype yaitu hasil desain sementara dari aplikasi yang berupa gambar.

Setelah melakukan perancangan berdasarkan kebutuhan user maka mengimplementasikan aplikasi yang telah di rancang keda dalam sebuah website. Pada tahap ini aplikasi web service automation telah selesai dibuat untuk di uji coba. Implementasi dari aplikasi ini dengan bertemu langsung kepada kepala toko dan meminta pendapat tentang kekurangan aplikasi ini. Dari hasil implementasi yang telah di lakukan 3 kali maka aplikasi ini dapat dilakukan pengujian.

Tahap berikutnya adalah melakukan pengujian dari aplikasi yakni melakukan testing menggunakan black box test, UAT dan skala likert. Pada tahap pengujian black box test ini dilakukan untuk menguji setiap fungsi berjalan dengan baik oleh prancang berbeda halnya dengan pengujian UAT dimana pengujian ini dilkukan bersama kepala toko dan staf admin untuk mengecek 
apakah semua sudah sesuai yang di harapkan. Pada pengujian skala likert yaitu pengujian dengan menggunakan kuisioner untuk pelanggan sebagai pengguna utama dari aplikasi ini, dalam pengisian kuisioner pelanggan menilai seberapa layak aplikasi ini digunakan.

Terakhir tahap melakukan analisa dan evaluasi yaitu membuat kesimpulan atas dasar pengujian yang telah dilakukan. Analisa yang dilakukan berdasarakan pengujiian black box test didapatkan hasil keseluruhan fungsional dari sistem berjalan baik dan hasil UAT yang nantinya menunjukkan bahwa aplikasi ini berhasil dan sangat layak.

\section{HASIL PENGEMBANGAN DAN PENGUJIAN APLIKASI}

Hasil dari penelitian ini menghasilkan produk web aplikasi yang dapat digunakan oelh 2 kategori aktor yaitu admin dan kasir. Gambaran penggunaan web aplikasi yang dibangun dapat dilihat pada gambar 3 hingga gambar 5

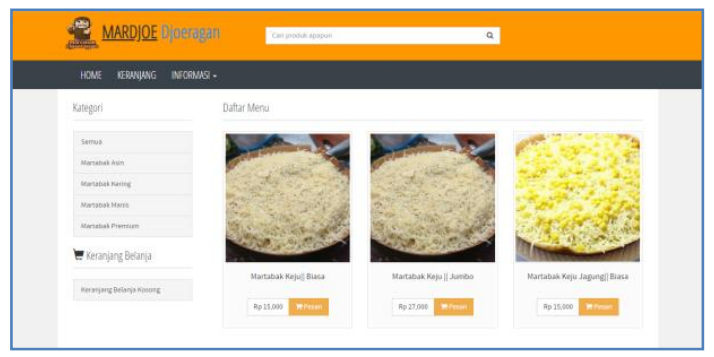

Gambar 3. Halaman Pemesanan Pelanggan

Pada gambar 3 merupakan halaman pemesanan utama pengguna pelanggan memesan menu martabak menggunakan web aplikasi. Proses pemesanan pelanggan yaitu pelanggan memilih menu produk dan jumlah unit beli kemudian mengisi nama dan nomor hp dan pilih tombol belanja.

Informasi tentang pesanan yang di pesan pelanggan akan muncul di halaman web aplikasi kasir dan kasir bertugas melakukan konfirmasi setiap pesanaan yang di bayar oleh pelanggan pada gambar 4.

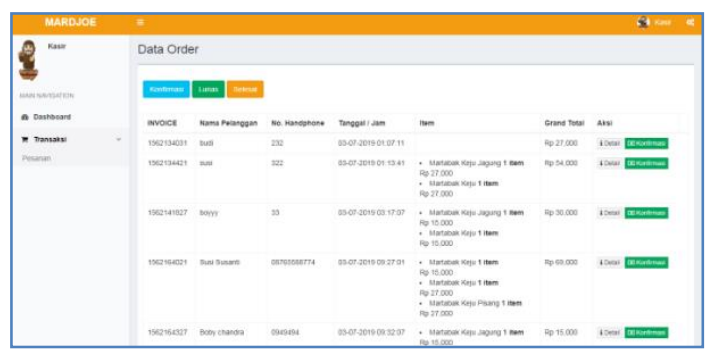

Gambar 4. Halaman Web Aplikasi Kasir

Setelah kasir melakukan konfirmasi setiap pesanan pelanggan maka data pesanan tersebut secara otomatis akan masuk ke dalam data transaksi di halaman admin. Pada halaman admin yaitu seorang kepala toko bertugas mengelolah produk dan membuat laporan transaksi penjualan. Gambar 5 merupakan halaman dashboard dari admin yang menampilkan grafik penjulan produk dalam kategori bulan, kategori produk dan produk.

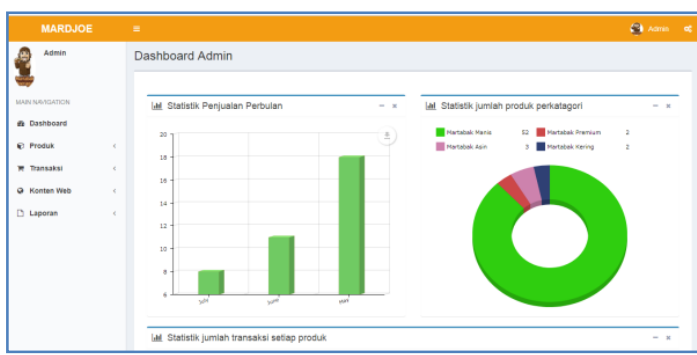

Gambar 5. Halaman Dasboard Admin

Setelah aplikasi dibangun lalu dilakukan pengujian yaitu pengujian Black Box Test, UAT dan Skala Likert.

Pengujian Black Box Testing yang telah dilakukan yaitu mendefinisikan kumpulan kondisi input dalam pengetesannya berfokus kepada spesifikasi fungsionalitas kebutuhan pengguna.

Analisis pengujian Black Box Testing berdasarkan hasil pengujian black box sebagai berikut :

Jumlah butir uji $(\mathrm{Tbu})=25$ butir uji

Jumlah butir uji sesuai (Bus) $=25$ butir uji

Jumlah butir uji gagal (Bug) $=0$ butir uji

Maka:

Persentase butir uji berhasil $=$

$$
\frac{B u b}{T b u} \times 100 \%=\frac{25}{25} \times 100 \%=100 \%
$$

Persentase butir uji gagal $=$

$$
\frac{B u g}{T b u} \times 100 \%=\frac{0}{25} \times 100 \%=0 \%
$$

Berdasarkan persentase pengujian butir uji yang dilakukan, dapat disimpulkan bahwa sebanyak 25 butir uji berjalan sesuai dengan harapan dan presentasi $100 \%$ berhasil.

Sedangkan pengujian User Acceptance Test (UAT) untuk menguji apakah fungsi sistem berjalan sesuai dengan yang diharapkan oleh pengguna yaitu kepala toko martabak djoeragan. Pengujian dilakukan secara langsung di toko martabak djoeragan durian pekanbaru bersama owner. Dalam pengujian ini terdapat 3 aktor dan terdapat 25 butir pengujian.

Dari semua butir uji dapat dihitung dengan menggunakan Perhitungan $U A T$ yaitu:

$$
U A T=\frac{\text { Jawaban } Y a}{\text { Jumlah Pertanyaan }} \times 100 \%
$$

Dengan menggunakan rumus, maka:

$$
U A T=\frac{25}{25} \times 100 \% U A T=100 \%
$$

Analisis dari pengujian setiap butir uji telah diterima oleh user sehingga persentase penerimaan fitur didapat sebesar $100 \%$, dengan demikian semua fitur pada sistem telah diimplementasikan dengan baik sesuai yang diharapkan oleh user sesuai dengan user requirement.

Setelah melakukan pengujian fungsional aplikasi, peneliti juga melakukan survei dengan metode skala likert yang dilakukan 
untuk melihat respon pelanggan atas hasil dari aplikasi ini. Pengujian dilakukan di toko martabak djoeragan durian pekanbaru. Pengujian ini berupa tanggapan dengan formulir kuesioner pertanyaan kepada pelanggan mengenai aplikasi ini. Analisis pengujian skala likert berdasarkan 30 orang responden pelanggan. Hal ini dilakukan secara langsung pada pelanggan asli yang sedang memesan dengan menggunakan aplikasi self service yang dibangun. Setelah memesan dan sembari menunggu pesanan selesai, maka pelanggan diminta untuk memberikan pendapat dengan mengisi kuesioner. Berdasarkan hasil pengumpulan data yang dilakukan maka rekapitulasi data diolah dengan menggunakan perhitungan skala likert, sehingga didaptlah nilai sebesar indeks $86 \%$ yang menyatakan bahwa web aplikasi yang dikembangkan masuk dalam kategori sangat layak untuk dijalankan.

\section{PENUTUP}

Berdasarkan analisis yang telah dilakukan pada penelitian ini, maka dapat disimpulkan bahwa perancangan dan pembangunan aplikasi service automation dengan menggunakan pedekatan customer self service telah diterima dan berhasil diimplementasikan dengan baik dan dapat memberikan kemudahan dalam bidang pelayanan.

Adapun saran yang dapat dijadikan pertimbangan untuk proyek akhir ini adalah aplikasi ini masih dapat dikembangkan dengan membuat teknologi apps smart phones dalam bidang pelayanan customer untuk melakukan pemesanan secara online dalam melayani pelanggan yang memesan di luar toko.

\section{REFERENCES}

[1] Lestari, W. L. (2018). Aplikasi Sistem Informasi Pembelian Dan Penjualan Pada Toko Citra Computer Cilacap. Jurnal Pro Bisnis, 3, 41-51.

[2] Putra, M. N., \& Winarno, A. (2011). Sistem Informasi Pengolahan Billing Pada Rumah Makan Padang Mahkota. Sistem Informasi, 5-11.

[3] Nugroho, J. S., \& Djajalaksana, Y. M. (2014). Aplikasi Web Reservasi Dan Penjualan Untuk Restoran. Jurnal Sistem Informasi, 127 - 147.

[4] Setiawan, Y., \& Susanti, E. (2013). Rancang Bangun Mesin Peminjaman Mandiri Dan Pengembalian Mandiri Bahan Pustaka Berbasis Komputer. E-Journal Gema Pustakawan, 38-71.

[5] Prabowo, S. (2016). Rancang Bangun Website Untuk Layanan Jasa Kuliner. Publikasi Ilmiah.

[6] Buttle, F., \& Maklan, S. (2015). Customer Relationship Management. In F. Buttle, Concepts And TechnologiesThird Edition. London and New York: Routledge.

[7] Prastya, I. (2018). Pengertian CRM (Customer Relationship Management) Menurut Para Ahli. Retrieved Agustus 30, 2018, From Pelajarindo.Com: Https://Pelajarindo.Com/Pengertian-Crm-CustomerRelationship-Management-Menurut-Para-Ahli/

[8] Rose, M. (2013). Customer Self-Service (CSS). Retrieved Agustus 19, 2018, From Whatis.Com: Https://Whatis.Techtarget.Com/Definition/Customer-SelfService-Css.
[9] Kadir, A. (2008). Tuntunan Praktis Belajar Database Menggunakan Mysql. Yogyakarta: Cv. Andi Offset.

[10] Fitri, R. (2017). Data Penjualan Martabak Djoeragan. Pekanbaru: Martabak Djoeragan 